\title{
Comparison of Mercury Distribution Between Liver and Muscle - A Biomonitoring of Fish from Lightly and Heavily Contaminated Localities
}

\author{
Marcela Havelková ${ }^{1, *}$, Ladislav Dušek ${ }^{2}$, Danka Némethová ${ }^{2}$, Gorzyslaw Poleszczuk ${ }^{3}$ and $^{1,4}$ \\ Zdeňka Svobodová ${ }^{1,4}$
}

1 University of Veterinary and Pharmaceutical Sciences, Faculty of Veterinary Hygiene and Ecology, Department of Public Health and Toxicology, Palackého 1-3, 612 42, Brno, Czech Republic

2 Masaryk University, Faculty of Medicine and Faculty of Science, Institute of Biostatistics and Analyses, Kamenice 126/3, 62500 Brno, Czech Republic

3 Szczecin University, Faculty of Natural Sciences, Chair of Chemistry, ul. Felczaka 3A, 71-412 Szczecin, Poland

4 University of South Bohemia in České Budějovice, Research Institute of Fish Culture and Hydrobiology, 38925 Vodňany, Czech Republic

* Author to whom correspondence should be addressed; E-mail: mhavelkova@vfu.cz

Received: 19 June 2008; in revised form: 6 July 2008 / Accepted: 6 July 2008 /

Published: 10 July 2008

\begin{abstract}
Tissue samples from 1,117 fish of 25 species were collected from 1991 through 1996 at 13 locations along the River Elbe. The principal indicator species were perch (Perca fluviatilis) ( $\mathrm{n}=118)$, chub (Leuciscus cephalus L.) $(\mathrm{n}=113)$ and roach (Rutilus rutilus) $(\mathrm{n}=138)$. Mercury $(\mathrm{Hg})$ concentrations in muscle and liver were determined by atomic absorption spectrometry. The liver/muscle index in three indicator species from heavily contaminated and lightly contaminated localities were significantly different. In fish from heavily contaminated localities, $\mathrm{Hg}$ was deposited preferentially in the liver (the depository for inorganic and organic forms of $\mathrm{Hg}$ ), while in lightly contaminated areas, it was deposited preferentially in muscle.
\end{abstract}

Keywords: $\mathrm{Hg}$ liver/muscle ratio, indicator fish, predator, non-predator, river contamination 


\section{Introduction}

Mercury $(\mathrm{Hg}$ ) belongs to major pollutants of the aquatic environment. Because of the extreme toxicity of its organic forms, its ability to bioaccumulate in aquatic organisms and its long-term persistence in sediments, mercury concentration in the environment needs to be closely monitored.

Although it is not a biogenic element in living organisms, $\mathrm{Hg}$ nevertheless accumulates in certain tissues. The highest $\mathrm{Hg}$ accumulations exist in aquatic organisms, specifically in fish. When it enters the aquatic environment, $\mathrm{Hg}$ is usually in its inorganic form and is transformed into the much more harmful, organic $\mathrm{Hg}$, through the process of methylation. The concentration and type of $\mathrm{Hg}$ also depends on the character of the sediment [1]. The association between concentrations of inorganic $\mathrm{Hg}$ in tissues and in sediments has been demonstrated [2, 3].

Metals are transferred from sediments to the food chain. The amount of $\mathrm{Hg}$ in the organism is affected by its position in the food chain [4-6], its size, age [2, 5, 7, 8] and duration of exposure [9]. There is also an association between $\mathrm{Hg}$ concentrations and fish weight [10, 11].

The main pathway for inorganic $\mathrm{Hg}$ intake into fish is the digestive tract, but other pathways are the skin and gills. Mercury is transported within the organism bound to blood plasma proteins. The liver, as the organ that participates in redistribution, detoxification and transformation of pollutants, is the target for inorganic $\mathrm{Hg}[8,12]$. Organic $\mathrm{Hg}$ de-methylated to its inorganic form in the liver.

Some authors believe that $\mathrm{Hg}$ distribution in fish tissues from heavily contaminated and lightly contaminated localities is different [10, 12, 13-16]. This was not corroborated by Wang et al. (2005) [17] in their study on frogs (Rana chensinensis), or by Honda et al. (1983) [9] or Chen et al. (2004) [18].

The aim of this study was to compare the distribution of $\mathrm{Hg}$ in fish tissues from heavily and lightly contaminated localities. The comparison was based on $\mathrm{Hg}$ concentrations in fish collected between 1991 and 1996 from several localities along the River Elbe as part of the "Elbe Project".

The River Elbe is one of the most extensive aquatic ecosystems in Central Europe. It is 1,091 km long (370.2 km of which are in the Czech Republic). Its extensive basin, an area of $148268 \mathrm{~km}^{2}$, lies within the boundaries of two countries, the Czech Republic and Germany. Pollution of the Elbe River originated mainly from inflow of water from catchment areas contaminated by municipal wastes and industrial discharges (chemical industries, paper mills, waste water works, shipbuilding yards) [19] and from tributaries of Elbe [20]. Thus sites located downstream of large cities along the river are the most representative models for long-term monitoring surveys and for the determination of levels of contamination. Significant sources of contamination, besides industrial and municipal waste, include agriculture, uncontrolled erosion, soil leaching and surface runoff.

\section{Materials and methods}

Fish tissue samples were collected between 1991 and 1996 at 13 sites along the River Elbe. The location and description of individual sites, and the number of fish collected at each site are given in Figure 1.

Lightly contaminated localities included Opatovice (typical lightly contaminated locality without significant anthropogenic influence) and localities upstream and downstream of the city of Pardubice 
(background sites). Heavily contaminated sites included areas upstream and downstream of the cities of Kolín (industrial and municipal waste), Čelákovice, Neratovice (chemical production), Štětí (paper mills), Lovosice (chemical industry), Vaňov (ship-building yard, docks), Ústí nad Labem (municipal waste, chemical industry, organic waste discharges), Děčín (municipal waste, chemical industry), and Hřensko (municipal waste, chemical industry) [6].

Figure 1. Geographical location of the sites (Czech Republic). The number of fish captured at individual sites is given in parenthesis.

Site 1 - Opatovice downstream $(n=120)$, Site 2 - Pardubice upstream $(n=98)$, Site 3 Pardubice downstream $(n=65)$, Site 4 - Kolín upstream $(n=48)$, Site 5 - Kolín downstream $(n=72)$, Site 6 - Čelákovice downstream $(n=69)$, Site 7 - Neratovice downstream $(n=77)$, Site 8 - Štětí downstream $(n=30)$, Site 9 - Lovosice downstream $(\mathrm{n}=75)$, Site 10 - Vaňov downstream $(\mathrm{n}=25)$, Site 11 - Ústí nad Labem downstream ( = 93), Site 12 - Děčín downstream $(n=279)$, Site 13 - Hřensko downstream $(n=66)$.

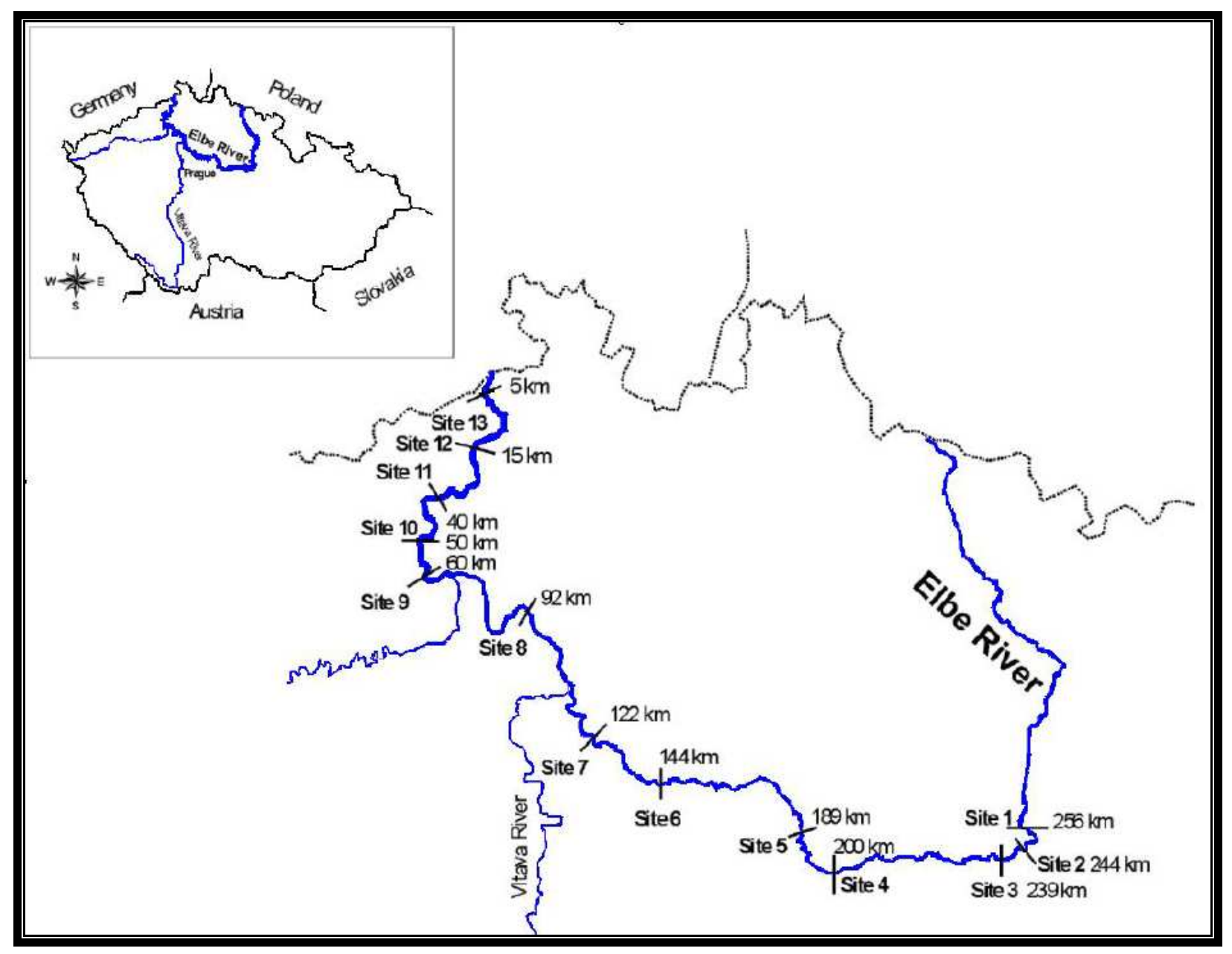

\subsection{Collection of fish samples}

Altogether 1,117 fish of 25 species were captured by electrofishing. All fish were captured in summer (from June to August). The fish species examined and their feeding habits are shown in Table 1. Fish were weighed and measured upon capture and their ages determined by scale analysis. Samples 
of muscle and liver were removed, placed in polyethylene bags, labelled, and transported in cooled containers to a freezer where they were stored at $-18^{\circ} \mathrm{C}$.

\subsection{Total mercury determination}

Total $\mathrm{Hg}$ tissue concentrations were determined by the AMA 254 single-purpose analyzer, which is based on combustion-amalgamation atomic absorption. No chemical pre-treatment of the samples was needed. A sample of fish tissue (liver or muscle) of known weight was placed on a sampling boat. By controlled heat, the sample was first dried and then thermally decomposed. The decomposition products were carried by oxygen flow to the second, catalytic section, of the instrument. The further decomposition products were then carried to an amalgamator which selectively traps mercury. Detection limit of $\mathrm{Hg}$ in the samples is $0.001 \mathrm{mg} \mathrm{kg}^{-1}$. Concentration of mercury in fish tissue is reported in terms of wet weight. Recovery of the method was $82 \pm 6 \%$. Mercury liver/muscle index was calculated for only 922 fish, because this was the number from which both liver and muscle were removed.

Concentrations of $\mathrm{Hg}$ in water along the River Elbe were also determined. No significant differences were found in concentrations of $\mathrm{Hg}$ in water between 1991 and 1996 at monitored localities.

Figure 2. The main indicator species - Perch (Perca fluviatilis).

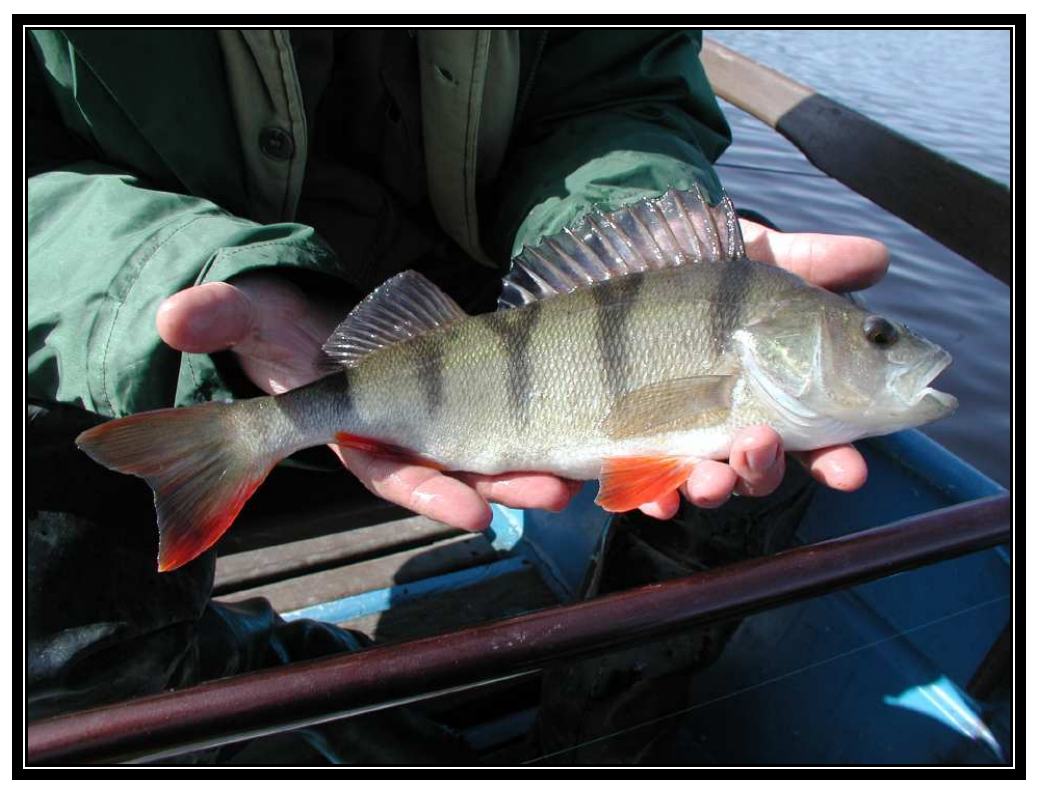

\subsection{Statistical analysis}

Distribution of each of the fish species in lightly and heavily contaminated localities was tested by mean of $X^{2}$ goodness-of-fit test. Only 15 species whose occurrence in lightly and heavily contaminated localities did not differ significantly were included in further analyses (Appendix 1 - Table 5).

To control for the affect of fish age on mercury concentration, linear regression was performed on each of the 15 species and mercury parameter (Appendix 2 - Table 6). The independent variable in the regression was fish age. The dependent variables were mercury concentration in liver, mercury concentration in muscle, and liver/muscle index. Regression residuals from linear regressions for each 
species and mercury parameter were saved. The values of these residuals were compared between heavily and lightly contaminated localities as well as between liver and muscle, considering only the mercury concentration which is not explained by fish age. Three largest indicator species groups (perch Perca fluviatilis, $\mathrm{n}=118$; chub Leuciscus cephalus, $\mathrm{n}=113$; roach Rutilus rutilus, $\mathrm{n}=138$ ) (Figures 2, 3 and 4) and groups comprising predators and non-predators were analysed.

Table 1. Examined fish species and their feeding habits.

\begin{tabular}{|c|c|c|}
\hline Fish species & Common name & Feeding guild \\
\hline Abramis brama & Bream & Benthophagous \\
\hline Alburnoides bipunctatus & Spirlin, riffle minnow & Planctivorous \\
\hline Alburnus alburnus & Bleak & Planctivorous \\
\hline Anguilla anguilla & European eel & Predator \\
\hline Aspius aspius & Asp & Predator \\
\hline Barbus barbus & Barbel & Benthophagous \\
\hline Blicca bjoerkna & White bream, silver bream & Benthophagous \\
\hline Carassius auratus & Gibel carp, goldfish & Planctivorous \\
\hline Esox lucius & Pike & Predator \\
\hline Gobio gobio & Gudgeon & Benthophagous \\
\hline Gymnocephalus cernuus & Ruffe, pope & Benthophagous \\
\hline Ictalurus nebulosus & Catfish, brown bullhead & Benthophagous \\
\hline Leuciscus cephalus & Chub & Omnivorous \\
\hline Leuciscus idus & Ide, orfe & Omnivorous \\
\hline Leuciscus leuciscus & Dace & Omnivorous \\
\hline Oncorhynchus mykiss & Rainbow trout & Predator \\
\hline Perca fluviatilis & Perch & Predator \\
\hline Rutilus rutilus & Roach & Benthophagous \\
\hline Salmo trutta & Trout & Predator \\
\hline Scardinius erythrophthalmus & Rudd & Phytophagous \\
\hline Silurus glanis & Wels, sheatfish & Predator \\
\hline Stizostedion lucioperca & Pikeperch, zander & Predator \\
\hline Tinca tinca & Tench & Benthophagous \\
\hline Thymallus thymallus & Grayling & Benthophagous \\
\hline Vimba vimba & Vimba bream & Benthophagous \\
\hline
\end{tabular}


The Kolmogorov-Smirnov test was used for assessing the normal distribution of residuals in perch, chub, roach, predator and non-predator in heavily and lightly contaminated localities. Almost all tests resulted in non-normal distribution of residuals in both heavily and lightly contaminated localities ( $\mathrm{P}<$ 0.05). This holds true for residuals of mercury concentration in liver and in muscle, as well as liver/muscle index. Therefore non-parametric tests were used to analyse the data. To compare values in heavily and lightly contaminated locations, the Mann-Whitney U test was used. A comparison between liver $\mathrm{Hg}$ levels and muscle $\mathrm{Hg}$ levels in fish from lightly as well as from heavily contaminated locations was performed using the Wilcoxon matched pairs test.

Figure 3. The main indicator species - Chub (Leuciscus cephalus L.).

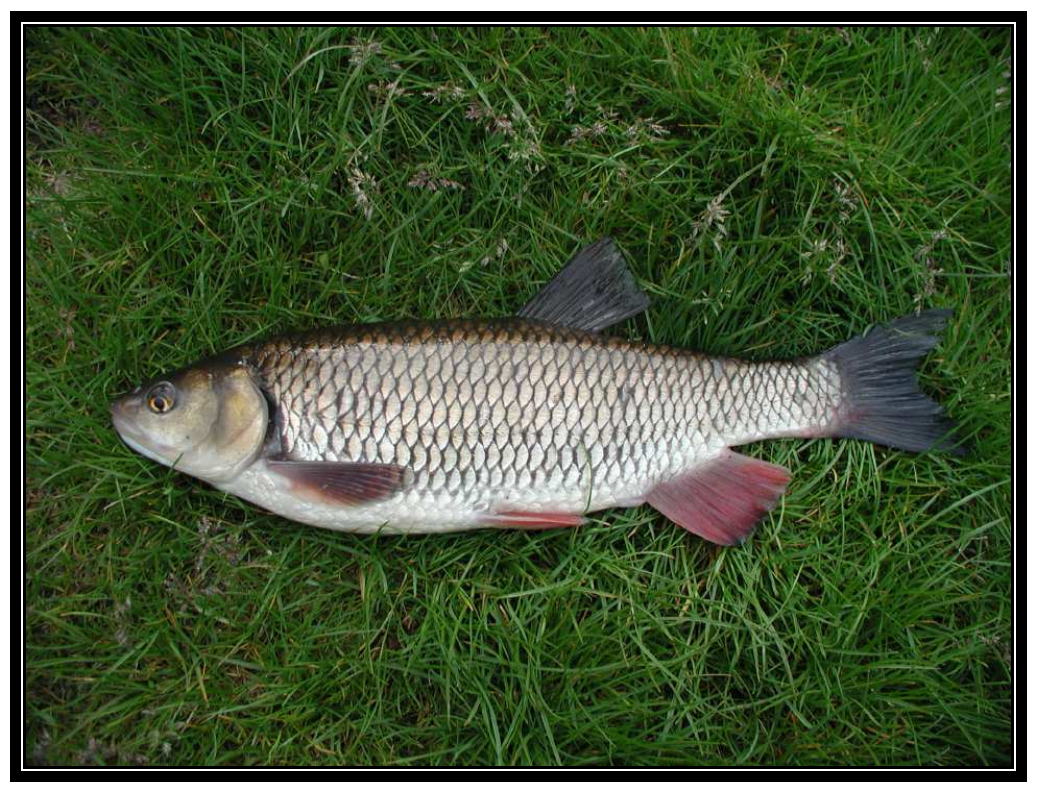

\section{Results}

To compare Hg levels in fish tissues from heavily contaminated and lightly contaminated localities, the liver/muscle index was used. The liver/muscle index is ratio of liver to muscle $\mathrm{Hg}$ concentrations $\left[\mathrm{Hg}\right.$ liver $\left(\mu \mathrm{g} \mathrm{g}^{-1}\right) / \mathrm{Hg}$ muscle $\left.\left(\mu \mathrm{g} \mathrm{g}^{-1}\right)\right]$. Mercury liver/muscle index adjusted for fish age, for three indicator fish species from heavily and lightly contaminated localities (perch, chub and roach) are given in Table 2. All of the ratios residuals were significantly higher $(\mathrm{P}<0.001$; Table 2$)$ in fish from heavily contaminated localities than from lightly contaminated localities. Mercury concentration in muscle was higher than in liver of three indicator fish species from lightly contaminated sites (Wilcoxon matched pairs test: perch: $\mathrm{n}=32$; $\mathrm{P}<0.001$; chub: $\mathrm{n}=29$; $\mathrm{P}<0.001$; roach: $\mathrm{n}=32$; $\mathrm{P}<$ 0.001). In heavily contaminated localities, Hg concentration in liver was higher than that in muscle, although the difference was statistically significant only in perch (Wilcoxon matched pairs test: perch: $\mathrm{n}=71 ; \mathrm{P}=0.012$; chub: $\mathrm{n}=82 ; \mathrm{P}=0.272$; roach: $\mathrm{n}=90 ; \mathrm{P}=0.360$ ). Differences in liver/muscle index (adjusted for age) were also found in predatory fish $(\mathrm{n}=208 ; \mathrm{U}=1192 ; \mathrm{P}<0.001)$ and non-predatory fish ( $\mathrm{n}=428 ; \mathrm{U}=3931$; $\mathrm{P}<0.001)$ when heavily and lightly contaminated localities were compared. The ratio residual for predatory fish from heavily contaminated localities (0.055) was higher than for non-predatory species (0.028), although the difference was not statistically significant $(\mathrm{n}=473$; $\mathrm{U}=$ 24735; P = 0.828). In lightly contaminated localities, the ratio residual in predatory fish was slightly, 
but not significantly, higher (-0.506) than in the non-predatory species $(-0.581)(\mathrm{n}=163 ; \mathrm{U}=2488 ; \mathrm{P}=$ 0.322). Mercury concentrations in liver and muscle change with the level of environmental contamination, and consequently the ratios change.

Mercury concentration, adjusted for age, in muscle and liver of three species of indicator fish from heavily and lightly contaminated localities are given in Tables 3 and 4. The highest concentrations of $\mathrm{Hg}$ were found in perch, the representative of predatory fish. Mercury content in muscle in the three indicator fish species differed significantly between heavily and lightly contaminated localities (in all three species $\mathrm{P}<0.001$; Table 3), being higher in heavily contaminated localities. The same holds true for liver $\mathrm{Hg}$ concentration residuals (in all three species $\mathrm{P}<0.001$; Table 4). A comparison among residuals of concentrations of $\mathrm{Hg}$ in liver and muscle of predatory and non-predatory fish species from heavily and lightly contaminated localities showed that the highest $\mathrm{Hg}$ concentrations were in the liver of predatory fish species from heavily contaminated localities $\left(0.063 \mu \mathrm{g} \mathrm{g}^{-1}\right)$. The lowest $\mathrm{Hg}$ concentrations were found in the liver of predatory fish from lightly contaminated localities $(-0.453 \mu \mathrm{g}$ $\left.\mathrm{g}^{-1}\right)$. In heavily contaminated localities, the residuals of muscle $\mathrm{Hg}$ concentrations were higher in predatory species than in non-predatory species. However, the difference was not significant $(\mathrm{n}=536$; $\mathrm{U}=30856 ; \mathrm{P}=0.278$ ). On the other hand, the difference was significant in lightly contaminated localities $(\mathrm{n}=163 ; \mathrm{U}=1413 ; \mathrm{P}<0.001)$. Similar results were also found in the liver. Residuals of liver $\mathrm{Hg}$ concentrations were higher in predatory than in non-predatory fish. The difference was not significant in heavily contaminated localities $(n=474 ; U=23017 ; P=0.136)$, but was significant in lightly contaminated localities $(\mathrm{n}=163 ; \mathrm{U}=1773 ; \mathrm{P}<0.001)$.

Table 2. Liver/ muscle index in three indicator fish species, predators and nonpredators, from heavily (HC) and lightly contaminated (LC) localities (effect of age subtracted).

\begin{tabular}{|c|c|c|c|c|c|c|c|c|}
\hline Fish species & $\begin{array}{c}\text { Locality } \\
\text { contamination }\end{array}$ & $\mathrm{N}$ & Mean & Median & Minimum & Maximum & Std.Dev. & $\begin{array}{l}\text { Mann-Whitney } \\
\text { U test }\end{array}$ \\
\hline \multirow{2}{*}{ PERCH } & $\mathrm{HC}$ & 71 & 0.202 & 0.139 & -0.791 & 1.514 & 0.549 & $\mathrm{U}=268$ \\
\hline & $\mathrm{LC}$ & 32 & -0.448 & -0.554 & -0.892 & 2.170 & 0.535 & $\mathrm{P}<0.001$ \\
\hline \multirow[t]{2}{*}{ CHUB } & $\mathrm{HC}$ & 82 & 0.148 & 0.068 & -0.553 & 2.537 & 0.488 & $\mathrm{U}=230$ \\
\hline & $\mathrm{LC}$ & 29 & -0.420 & -0.487 & -0.783 & 0.835 & 0.320 & $\mathrm{P}<0.001$ \\
\hline \multirow[t]{2}{*}{$\mathrm{ROACH}$} & $\mathrm{HC}$ & 90 & 0.242 & -0.105 & -0.738 & 5.669 & 1.075 & $\mathrm{U}=187$ \\
\hline & $\mathrm{LC}$ & 32 & -0.680 & -0.721 & -1.002 & -0.005 & 0.197 & $\mathrm{P}<0.001$ \\
\hline \multirow[t]{2}{*}{ PREDATOR } & $\mathrm{HC}$ & 160 & 0.154 & 0.055 & -1.592 & 3.190 & 0.687 & $\mathrm{U}=1192$ \\
\hline & $\mathrm{LC}$ & 48 & -0.512 & -0.506 & -1.658 & 2.170 & 0.542 & $\mathrm{P}<0.001$ \\
\hline \multirow[t]{2}{*}{$\begin{array}{c}\text { NO } \\
\text { PREDATOR }\end{array}$} & $\mathrm{HC}$ & 313 & 0.217 & 0.028 & -0.963 & 5.669 & 0.812 & $\mathrm{U}=3931$ \\
\hline & $\mathrm{LC}$ & 115 & -0.590 & -0.581 & -1.959 & 1.189 & 0.409 & $\mathrm{P}<0.001$ \\
\hline
\end{tabular}

Distribution of fish species in heavily and lightly contaminated localities and regression equations of effect of age on mercury concentration in muscle, liver and liver and muscle mercury concentration ratio are shown in Appendix 1 (Table 5) and Appendix 2 (Table 6). 


\section{Discussion}

A comparison between $\mathrm{Hg}$ concentrations in tissues of fish from heavily contaminated and lightly contaminated localities showed the existence of differing mercury distribution in fish from those localities. In all three indicator fish species, the liver/muscle index was significantly higher (Table 2) in fish from heavily contaminated localities than in fish from lightly contaminated localities. While the target organ for $\mathrm{Hg}$ accumulation in fish from heavily contaminated localities was the liver, the main target organ for $\mathrm{Hg}$ accumulation in fish from lightly contaminated localities was muscle.

The distribution of mercury in muscles and internal organs of fish depends, inter alia, on the degree of contamination of the environment $[10,21]$. The liver was selected for analysis because it is a good indicator of environmental pollution. The liver has the ability to accumulate large quantities of pollutants from the external environment, and also plays an important role in storage, redistribution, detoxification, and transformation of pollutants [22]. Higher $\mathrm{Hg}$ concentration in liver compared with that in muscle has been corroborated by Kennedy (2003) [15] and Gonzalez et al. (2005) [16], who exposed fish (common goldfish, Carassius auratus and zebrafish, Danio rerio, respectively) to various $\mathrm{Hg}$ concentrations. Data from the literature indicate that when $\mathrm{Hg}$ concentrations in fish muscle are low (below approximately $0.5 \mu \mathrm{g} \mathrm{g}^{-1}$ ), $\mathrm{Hg}$ concentration in muscle is about twice that in liver. When higher muscle concentrations of $\mathrm{Hg}$ are reached $\left(>1 \mu \mathrm{g} \mathrm{g}^{-1}\right.$ ), the ratio is reversed, and $\mathrm{Hg}$ concentrations in the liver will be several times higher than that in muscle [23].

In $\mathrm{Hg}$-polluted locations, $\mathrm{Hg}$ concentrations in internal organs are usually significantly higher than $\mathrm{Hg}$ concentrations in muscle [10, 24]. In their study of sea bass (Dicentrarchus labrax) from heavily contaminated localities, Abreu et al. (2000) [10] found up to twice the Hg concentration in the liver as in muscle.

Table 3. Muscle concentration ( $\mu g g-1)$ in three indicator fish species, predators and non-predators, from heavily (HC) and lightly contaminated (LC) localities (effect of age subtracted).

\begin{tabular}{lcccccccc}
\hline \multirow{2}{*}{ Fish species } & $\begin{array}{c}\text { Locality } \\
\text { contamination }\end{array}$ & $\mathrm{N}$ & Mean & Median & Minimum & Maximum & Std.Dev. & $\begin{array}{c}\text { Mann-Whitney } \\
\text { U test }\end{array}$ \\
\hline PERCH & HC & 86 & 0.152 & 0.043 & -0.842 & 3.941 & 0.647 & $\mathrm{U}=351$ \\
& $\mathrm{LC}$ & 32 & -0.407 & -0.370 & -0.820 & -0.038 & 0.213 & $\mathrm{P}<0.001$ \\
\hline \multirow{2}{*}{ CHUB } & $\mathrm{HC}$ & 84 & 0.142 & -0.100 & -0.365 & 2.564 & 0.554 & $\mathrm{U}=110$ \\
& $\mathrm{LC}$ & 29 & -0.412 & -0.432 & -0.558 & -0.069 & 0.127 & $\mathrm{P}<0.001$ \\
\hline \multirow{2}{*}{ ROACH } & HC & 104 & 0.062 & 0.014 & -0.207 & 1.180 & 0.198 & $\mathrm{U}=54.5$ \\
& $\mathrm{LC}$ & 32 & -0.200 & -0.192 & -0.308 & -0.094 & 0.042 & $\mathrm{P}<0.001$ \\
\hline \multirow{2}{*}{ PREDATOR } & HC & 188 & 0.107 & 0.060 & -0.842 & 3.941 & 0.481 & $\mathrm{U}=705$ \\
& $\mathrm{LC}$ & 48 & -0.417 & -0.370 & -1.030 & -0.038 & 0.202 & $\mathrm{P}<0.001$ \\
\hline \multirow{2}{*}{ NO PREDATOR } & HC & 348 & 0.087 & 0.012 & -0.558 & 2.564 & 0.352 & $\mathrm{U}=3627.5$ \\
& LC & 115 & -0.264 & -0.228 & -0.558 & 0.024 & 0.140 & $\mathrm{P}<0.001$ \\
\hline
\end{tabular}


The fact that $\mathrm{Hg}$ concentration in muscle of fish captured from lightly contaminated localities is usually higher than that found in their internal organs (liver, kidney) has been reported in studies of common carp (Cyprinus carpio) [12], seven species of fish from the Skalka reservoir [24], pike-perch (Stizostedion lucioperca L.) and bream (Abramis brama) from Lake Balaton in Hungary [14], tusks (Brosme brosme) captured off the coastline (a lightly contaminated locality) [13], and Odontotesthes microlepidotus from lightly contaminated localities [25]. Mercury distribution in lightly contaminated localities seems to take the following pattern: muscle > kidney > liver > gonads [26, 27]. Higher $\mathrm{Hg}$ concentrations in muscle compared to liver have been reported in fish from Otradovice, a lightly contaminated locality in the River Jizera [28]; in tissue of fish from some selected lightly contaminated ponds studied for metal concentrations in tissues [29]; and in European eel (Anguilla anguilla) and brown trout (Salmo trutta) from the River Ferrerias in Spain (a lightly contaminated locality) [30].

Figure 4. The main indicator species - Roach (Rutilus rutilus).

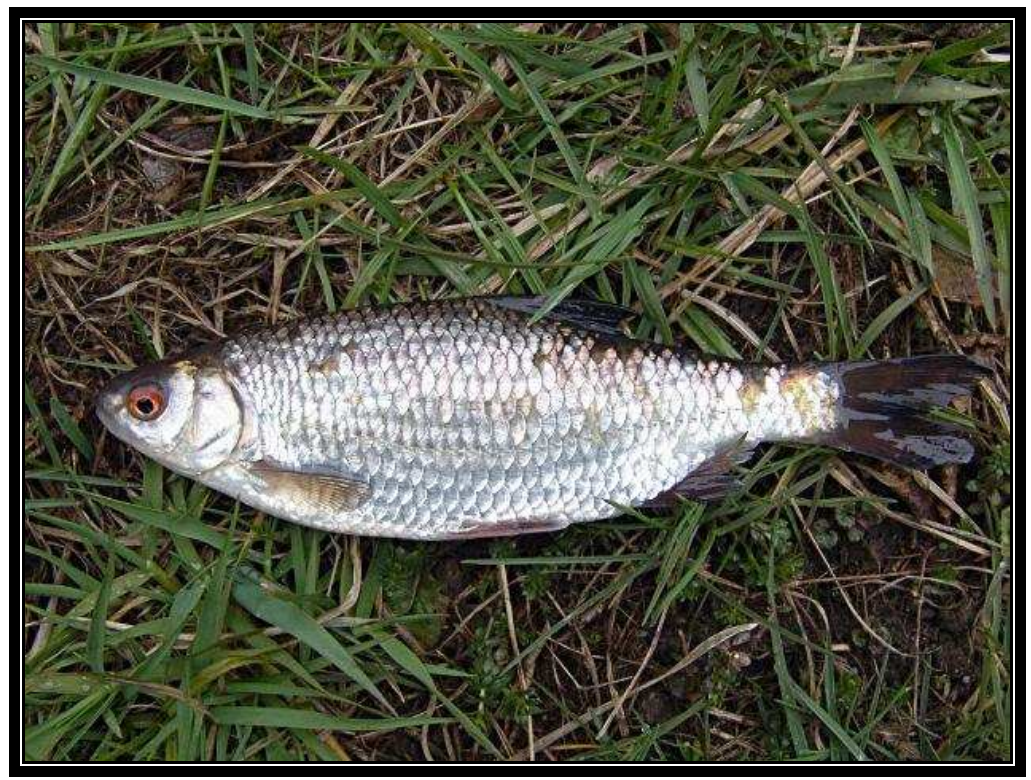

In their study on Rana Chensinensis from both heavily contaminated localities and lightly contaminated localities, Wang et al. (2005) [17], on the other hand, demonstrated an average of 50\% higher $\mathrm{Hg}$ concentration in the liver than in muscle. Honda et al. (1983) [9] found $\mathrm{Hg}$ concentrations in liver to be twice that in muscle in Pagothenia borchgreinki from the Antarctic, an area free of any significant anthropogenic pollution with heavy metals. Similar conclusions have been drawn by Chen et al. (2004) [18], who measured tissue $\mathrm{Hg}$ concentration in localities with different levels of contamination. In most cases, liver $\mathrm{Hg}$ concentrations were higher than muscle $\mathrm{Hg}$ concentrations irrespective of the degree to which the location was polluted.

Mercury concentrations in fish tissues from heavily and lightly contaminated localities differed in accordance with feeding habits of individual species. Mercury concentrations in predatory fish tissues were significantly higher than those of non-predatory fish $(\mathrm{P}<0.001)$. The amount of $\mathrm{Hg}$ accumulated in fish tissues is related to their position in the food chain. Older predatory fish, as the end link of the food chain, show higher $\mathrm{Hg}$ concentrations than non-predatory fish [6, 8]. Also, the diet of predatory 
fish is richer in lipids, giving the liver a greater capacity for storing lipid-soluble methylmercury than that of non-predatory fish. Piscivores tend to have a higher liver/muscle index compared with nonpiscivorous species. In nonpiscivores, the liver/muscle index is approximately one-to-two, while in piscivores the ratio is near one-to-one [23].

Mercury occurs in two basic forms in fish tissues, the inorganic form and the organic form, methylmercury. The two forms of $\mathrm{Hg}$ differ in concentration and distribution in the fish body. Methylmercury is preferentially distributed to muscle, where it binds to protein-rich cystein (in sarcoplasmatic proteins). Methylmercury concentration in muscle follows total $\mathrm{Hg}$ concentrations, and the methylmercury to total $\mathrm{Hg}$ ratio in muscle usually exceeds $80 \%$ [1]. Thus in muscle, $\mathrm{Hg}$ occurs mostly as its organic form, in contrast to the liver, where accumulation is mostly of the inorganic [8, $12,24,31-34]$.

Table 4. Liver concentration $\left(\mu \mathrm{gg}^{-1}\right)$ in three indicator fish species, predators and nonpredators, from heavily (HC) and lightly contaminated (LC) localities (effect of age subtracted).

\begin{tabular}{lcccccccc}
\hline \multirow{2}{*}{ Fish species } & $\begin{array}{c}\text { Locality } \\
\text { contaminatio }\end{array}$ & $\mathrm{N}$ & Mean & Median & Minimum & Maximum & Std.Dev. & $\begin{array}{c}\text { Mann-Whitney } \\
\text { U test }\end{array}$ \\
\hline PERCH & $\mathrm{n}$ & & & & & & & \\
& $\mathrm{HC}$ & 71 & 0.225 & 0.113 & -0.973 & 2.028 & 0.549 & $\mathrm{U}=166$ \\
& $\mathrm{LC}$ & 32 & -0.500 & -0.440 & -0.899 & -0.075 & 0.210 & $\mathrm{P}<0.001$ \\
\hline CHUB & $\mathrm{HC}$ & 82 & 0.182 & -0.059 & -0.546 & 3.950 & 0.794 & $\mathrm{U}=158$ \\
& $\mathrm{LC}$ & 29 & -0.515 & -0.523 & -0.764 & -0.209 & 0.168 & $\mathrm{P}<0.001$ \\
\hline ROACH & $\mathrm{HC}$ & 91 & 0.123 & -0.037 & -0.323 & 2.669 & 0.473 & $\mathrm{U}=46$ \\
& $\mathrm{LC}$ & 32 & -0.349 & -0.341 & -0.473 & -0.239 & 0.062 & $\mathrm{P}<0.001$ \\
\hline PREDATOR & $\mathrm{HC}$ & 160 & 0.170 & 0.063 & -1.283 & 3.379 & 0.679 & $\mathrm{U}=830$ \\
& $\mathrm{LC}$ & 48 & -0.566 & -0.453 & -1.846 & -0.075 & 0.295 & $\mathrm{P}<0.001$ \\
\hline \multirow{2}{*}{ NO PREDATOR } & HC & 314 & 0.158 & -0.031 & -0.684 & 3.950 & 0.605 & $\mathrm{U}=2939$ \\
& $\mathrm{LC}$ & 115 & -0.431 & -0.369 & -1.278 & 0.015 & 0.222 & $\mathrm{P}<0.001$ \\
\hline
\end{tabular}

\section{Conclusion}

In conclusion, the liver is the organ where de-methylation of the organic form of $\mathrm{Hg}$ to the less toxic inorganic form takes place [35], and where the latter is stored and metabolized. The methylmercury to total $\mathrm{Hg}$ ratio in the liver is lower than that in muscle. A comparison between $\mathrm{Hg}$ concentrations in tissues showed the existence of differing $\mathrm{Hg}$ distributions in fish from heavily contaminated and lightly contaminated localities. These results indicate that fish are able to tolerate low $\mathrm{Hg}$ concentrations. If $\mathrm{Hg}$ concentrations in tissues exceed $1 \mu \mathrm{g} \mathrm{g}^{-1} \mathrm{Hg}$ is redistributed from muscle, which leads to an increase of $\mathrm{Hg}$ concentration in the liver. 


\section{Acknowledgements}

This study was supported by the Ministry of Education Youth and Sports of the Czech Republic (MSM Project No. 6215712402 and MSM Project No. 0021622412).

\section{References and Notes}

1. Kannan, K.; Smith, R.G.; Lee, R.F.; Windom, H.L.; Heitmuller, P.T.; Macauley, J.M.; Summers, J.K. Distribution of total mercury and methylmercury in water, sediment, and fish from south Florida estuaries. Arch. Environ. Con. Tox. 1998, 34, 109-118.

2. Park, J.G.; Curtis, L.R. Mercury distribution in sediments and bioaccumulation by fish in two Oregon reservoirs: point-source and nonpoint-source impacted systems. Arch. Environ. Con. Tox. 1997, 33, 423-429.

3. Mzoughi, N.; Stoichev, T.; Dachraoui, M.; El Abed, A.; Amouroux, D.; Donard, O.F.X. Inorganic mercury and methylmercury in surface sediments and mussel tissues from a microtidal lagoon (Bizerte, Tunisia). J. Coast. Conserv. 2002, 8, 141-145.

4. Rincon-Leon, F.; Zurera-Cosano, G.; Moreno-Rojas, R.; Amaro-Lopez, M. Importance of eating habits and sample size in the estimation of environmental mercury contamination using biological indicators. Environ. Monit. Assess. 1993, 27, 193-200.

5. Cizdziel, J.V.; Hinners, T.A.; Pollard, J.E.; Heithmar, E.M.; Cross, C.L. Mercury concentrations in fish from Lake Mead, USA, related to fish size, condition, trophic level, location, and consumption risk. Arch. Environ. Con. Tox. 2002, 43, 309-317.

6. Dušek, L.; Svobodová, Z.; Janoušková, D.; Vykusová, B.; Jarkovský, J.; Šmid, R.; Pavliš, P. Bioaccumulation of mercury in muscle tissue of fish in the Elbe River (Czech Republic): multispecies monitoring study 1991-1996. Ecotox. Environ. Safe. 2005, 61, 256-267.

7. Phillips, C.R.; Heilprin, D.J.; Hart, M.A. Mercury accumulation in barred sand bass (Paralabrax nebulifer) near a large wastewater outfall in the Southern California Bight. Mar. Pollut. Bull. 1997, 34, 96-102.

8. Yamashita, Y.; Omura, Y.; Okazaki, E. Total mercury and methylmercury levels in commercially important fishes in Japan. Fisheries Sci. 2005, 71, 1029-1035.

9. Honda, K.; Sahrul, M.; Hidaka, H.; Tatsukawa, R. Organ and tissue distribution of heavy metals, and their growth-related changes in Antarctic fish, Pagothenia borchgrevinki. Agr. Biol. Chem. Tokyo. 1983, 47, 2521-2532.

10. Abreu, S.N.; Pereira, E.; Vale, C.; Duarte, A.C. Accumulation of mercury in sea bass from a contaminated lagoon (Ria de Aveiro, Portugal). Mar. Pollut. Bull. 2000, 40, 293-297.

11. Farkas, A.; Salanki, J.; Specziar, A. Age- and size-specific patterns of heavy metals in the organs of freshwater fish Abramis brama L. populating a low contaminated site. Water Res. 2003, 37, 959-964.

12. Maršálek, P.; Svobodová, Z.; Randák, T. The content of total mercury in common carp from selected Czech ponds. Aquacult. Int. 2007, 3-4, 299-304. 
13. Berg, V.; Ugland, K.I.; Hareide, N.R.; Groenningen, D.; Skaare, J.U. Mercury, cadmium, lead, and selenium in fish from a Norwegian fjord and off the coast, the importance of sampling locality. $J$. Environ. Monitor. 2000, 2, 375-377.

14. Farkas, A.; Salanki, J.; Varanka, I. Heavy metal concentrations in fish of Lake Balaton. Lake Reserv. Manage. 2000, 5, 271-279.

15. Kennedy, C.J. Uptake and accumulation of mercury from dental amalgam in the common goldfish, Carassius auratus. Environ. Pollut. 2003, 121, 321-326.

16. Gonzalez, P.; Dominique, Y.; Massabuau, J.C.; Boudou, A.; Bourdineaud, J.P. Comparative effects of dietary methylmercury on gene expression in liver, skeletal muscle, and brain of the zebrafish (Danio rerio). Environ. Sci. Technol. 2005, 39, 3972-3980.

17. Wang, N.; Zhu, Y.M.; Sheng, L.X.; Meng, D. Mercury pollution in Rana Chensinensis in Weisha river reach, in the upstream region of Songhua river. Chinese Sci. Bull. 2005, 50, 2166-2170.

18. Chen, Y.C.; Chen, C.Y.; Hwang, H.J.; Chang, W.B.; Yeh, W.J.; Chen, M.H. Comparison of the metal concentrations in muscle and liver tissues of fishes from the Erren River, southwestern Taiwan, after the restoration in 2000. J. Food Drug Anal. 2004, 12, 358-366.

19. Havelkova, M.; Blahova, J.; Kroupova, H.; Randak, T.; Slatinska, I.; Leontovycova, D.; Grabic, R.; Pospisil, R.; Svobodova, Z. Biomarkers of contaminant exposure in Chub (Leuciscus cephalus L.) - a biomonitoring of major rivers in the Czech Republic. Sensors 2008, 8, 2589-2603.

20. Havelkova, M.; Randak, T.; Zlabek, V.; Krijt, J.; Kroupova, H.; Pulkrabova, J.; Svobodova, Z. Biochemical markers for assessing aquatic contamination. Sensors 2008, 7, 2599-2611.

21. Cizdziel, J.V.; Hinners, T.A.; Cross, C.L.; Pollard, J.E. Distribution of mercury in the tissues of five species of freshwater fish from Lake Mead, USA. J. Environ. Monitor. 2003, 5, 802-807.

22. Evans, D.W.; Dodoo, D.K.; Hanson, P.J. Trace-element concentrations in fish livers: implications of variations with fish size in pollution monitoring. Mar. Pollut. Bull. 1993, 26, 329-334.

23. Goldstein, R.M.; Brigham, M.E.; Stauffer, J.C. Comparison of mercury concentrations in liver, muscle, whole bodies, and composites of fish from the Red River of the North. Can. J. Fish. Aquat. Sci. 1996, 53, 244-252.

24. Maršálek, P.; Svobodová, Z.; Randák, T.; Švehla, J. Total mercury and methylmercury contamination of fish from the Skalka reservoir: a case study. Acta Vet. Brno. 2005, 74, 427-434.

25. Arribere, M.A.; Guevara, S.R.; Sánchez, R.S.; Gil, M.I.; Ross, G.R.; Daurade, L.E.; Fajon, V.; Horvat, M.; Alcalde, R.; Kestelman, A.J. Heavy metals in the vicinity of a chlor-alkali factory in the upper Negro River ecosystem, Northern Patagonia, Argentina. Sci. Total Environ. 2003, 301, 187-203.

26. Svobodová, Z.; Piačka, V.; Vykusová, B.; Máchová, J.; Hejtmánek, M.; Hrbková, M.; Bastl, J. Residues of pollutants in siluriformes from various localities of the Czech Republic. Acta Vet. Brno. 1995, 64, 195-208.

27. Foster, E.P.; Drake, D.L.; DiDomenico, G. Seasonal changes and tissue distribution of mercury in largemouth bass (Micropterus salmoides) from Dorena Reservoir, Oregon. Arch. Environ. Con. Tox. 2000, 38, 78-82. 
28. Svobodová, Z.; Vykusová, B.; Máchová, J.; Bastl, J.; Hrbková, M.; Svobodník, J. Monitoring of foreign substances in fishes from the Jizera River in the Otradovice locality. Bulletin VURH Voď̌any. 1993, 29, 28-42.

29. Svobodová, Z.; Žlábek, V.; Čelechovská, O.; Randák, T.; Máchová, J.; Kolářová, J. Content of metals in tissues of marketable common carp and in bottom sediments of selected ponds of South and West Bohemia. Czech J. Anim. Sci. 2002, 47, 339-350.

30. Linde, A.R.; Sanchez-Galan, S.; Garcia-Vazquez, E. Heavy metal contamination of European eel (Anguilla anguilla) and brown trout (Salmo trutta) caught in wild ecosystems in Spain. J. Food Protect. 2004, 67, 2332-2336.

31. Joiris, C.R.; Holsbeek, L.; Moatemri, N.L. Total and methylmercury in sardines Sardinella aurita and Sardina pilchardus from Tunisia. Mar. Pollut. Bull. 1999, 38, 188-192.

32. Storelli, M.M.; Marcotrigiano, G.O. Heavy metal residues in tissues of marine turtles. Mar. Pollut. Bull. 2003, 46, 397-400.

33. Storelli, M.M.; Storelli, A.; Giacominelli-Stuffler, R.; Marcotrigiano, G. O. Mercury speciation in the muscle of two commercially important fish, hake (Merluccius merluccius) and striped mullet (Mullus barbatus) from the Mediterranean sea: estimated weekly intake. Food Chem. 2005, 89, 295-300.

34. Voegborlo, R.B.; Matsuyama, A.; Akagi, H.; Adimado, A.A.; Ephraim, J.H. Total mercury and methylmercury accumulation in the muscle tissue of frigate (Auxis thazard thazard) and yellow fin (Thunnus albacares) tuna from the Gulf of Guinea, Ghana. B. Environ. Contam. Tox. 2006, 76, 840-847.

35. Young, R.A. Toxicity summary for methylmercury. Oak Ridge Resevation Environmental Restoration Program (RAIS: Methyl Mercury (2269-92-6)), 1992. http://risk.lsd.ornl.gov/tox/profiles/methyl_mercury_f_V1.shtml. 
Appendix 1. (Table 5) Distribution of fish species in heavily and lightly contaminated localities. Occurence of species marked with asterisk in lightly and heavily contaminated localities differed significantly. ( $\mathrm{N}$ - number of individuals; X2-goodnessof-fit test used)

\begin{tabular}{|c|c|c|c|c|}
\hline Fish species & $\mathbf{N}$ & $\mathbf{X}^{2}$ & df & $\begin{array}{c}\text { Significanc } \\
\text { e level }\end{array}$ \\
\hline Abramis brama * & 137 & 10.203 & 1 & $P=0.001$ \\
\hline Alburnus alburnus * & 73 & 6.662 & 1 & $P=0.010$ \\
\hline Anguilla anguilla & 30 & 2.602 & 1 & $P=0.107$ \\
\hline Aspius aspius & 21 & 3.368 & 1 & $P=0.066$ \\
\hline Barbus barbus & 32 & 1.749 & 1 & $P=0.186$ \\
\hline Blicca bjoercna & 66 & 3.289 & 1 & $P=0.070$ \\
\hline Carassius auratus & 27 & 1.749 & 1 & $\mathrm{P}=0.186$ \\
\hline Cyprinus carpio * & 27 & 14.479 & 1 & $\mathrm{P}<0.001$ \\
\hline Esox lucius * & 49 & 4.631 & 1 & $P=0.031$ \\
\hline Gobio gobio * & 60 & 35.875 & 1 & $\mathrm{P}<0.001$ \\
\hline Gymnocephalus cernua & 4 & 2.321 & 1 & $P=0.128$ \\
\hline Ictalurus nebulosus * & 35 & 7.185 & 1 & $\mathbf{P}=\mathbf{0 . 0 0 7}$ \\
\hline Leuciscus cephalus & 113 & 0.019 & 1 & $P=0.892$ \\
\hline Leuciscus idus & 38 & 0.045 & 1 & $\mathrm{P}=0.833$ \\
\hline Leuciscus leuciscus & 10 & 5.820 & 1 & $P=0.016$ \\
\hline Perca fluviatilis & 118 & 0.272 & 1 & $P=0.602$ \\
\hline Rutilus rutilus & 138 & 0.266 & 1 & $P=0.606$ \\
\hline Salmo trutta & 5 & 2.321 & 1 & $P=0.128$ \\
\hline Scardinius erythrophthalmus * & 29 & 15.030 & 1 & $P<0.001$ \\
\hline Stizostedion lucioperca & 63 & 3.343 & 1 & $P=0.067$ \\
\hline Tinca tinca & 29 & 1.292 & 1 & $P=0.256$ \\
\hline Vimba vimba & 8 & 0.600 & 1 & $\mathrm{P}=0.439$ \\
\hline Lota lota & 2 & & & \\
\hline Silurus glanis & 2 & & & \\
\hline Thymallus thymallus & 1 & & & \\
\hline Predator vs. no predator & 702 & 1.759 & 1 & $\mathrm{P}=0.185$ \\
\hline
\end{tabular}


Appendix 2. (Table 6) Regression equations of effect of age on mercury concentration in muscle, liver and liver and muscle mercury concentration ratio. (Fish species with different distribution in heavily and lightly contaminated localities were not included.)

\begin{tabular}{|c|c|c|c|c|c|c|c|c|c|c|c|c|}
\hline & \multicolumn{3}{|c|}{ Hg in muscle } & \multicolumn{4}{|c|}{ Hg in liver } & \multicolumn{5}{|c|}{$\mathrm{Hg}$ in liver / $\mathrm{Hg}$ in muscle } \\
\hline & intercept & slope & $\mathbf{r}^{2}$ & $\mathbf{P}$ & intercept & slope & $\mathbf{r}^{2}$ & $\mathbf{P}$ & intercept & slope & $\mathbf{r}^{2}$ & $\mathbf{P}$ \\
\hline Anguilla anguilla & 0.526 & -0.010 & 0.004 & 0.726 & 1.085 & -0.012 & 0.001 & 0.911 & 1.674 & 0.037 & 0.002 & 0.825 \\
\hline Aspius aspius & 0.491 & 0.135 & 0.197 & 0.044 & 2.120 & -0.021 & 0.001 & 0.923 & 3.027 & -0.242 & 0.096 & 0.196 \\
\hline Barbus barbus & 0.233 & 0.070 & 0.036 & 0.296 & 0.089 & 0.077 & 0.038 & 0.287 & 0.344 & 0.073 & 0.058 & 0.183 \\
\hline Blicca bjoercna & 0.358 & 0.006 & 0.003 & 0.689 & -0.002 & 0.118 & 0.089 & 0.025 & 0.569 & 0.147 & 0.064 & 0.060 \\
\hline Carassius auratus & 0.173 & 0.016 & 0.105 & 0.099 & 0.088 & 0.004 & 0.016 & 0.534 & 0.489 & -0.005 & 0.002 & 0.835 \\
\hline Gymnocephalus cernua & 0.212 & -0.011 & 0.228 & 0.523 & & & & & & & & \\
\hline Leuciscus cephalus & 0.308 & 0.032 & 0.018 & 0.161 & 0.058 & 0.080 & 0.051 & 0.017 & 0.418 & 0.071 & 0.085 & 0.002 \\
\hline Leuciscus idus & 0.350 & -0.011 & 0.013 & 0.493 & 0.458 & -0.004 & 0.000 & 0.931 & 0.605 & 0.106 & 0.032 & 0.294 \\
\hline Leuciscus leuciscus & 0.229 & 0.042 & 0.447 & 0.035 & 0.283 & 0.008 & 0.006 & 0.839 & 1.045 & -0.062 & 0.051 & 0.531 \\
\hline Perca fluviatilis & -0.147 & 0.335 & 0.254 & $<0.001$ & -0.226 & 0.379 & 0.335 & $<0.001$ & 0.925 & 0.056 & 0.009 & 0.328 \\
\hline Rutilus rutilus & 0.236 & 0.015 & 0.018 & 0.116 & 0.255 & 0.028 & 0.013 & 0.218 & 0.855 & 0.048 & 0.007 & 0.346 \\
\hline Salmo trutta & 0.289 & -0.082 & 0.435 & 0.341 & & & & & & & & \\
\hline Stizostedion lucioperca & 0.710 & -0.023 & 0.010 & 0.427 & 0.583 & -0.005 & 0.000 & 0.913 & 0.881 & -0.014 & 0.002 & 0.708 \\
\hline Tinca tinca & 0.692 & -0.047 & 0.106 & 0.085 & 0.434 & -0.021 & 0.010 & 0.625 & 0.656 & -0.017 & 0.007 & 0.693 \\
\hline Vimba vimba & 0.746 & -0.052 & 0.030 & 0.682 & 0.177 & 0.124 & 0.016 & 0.763 & -1.050 & 0.492 & 0.132 & 0.377 \\
\hline
\end{tabular}

(C) 2008 by the authors; licensee Molecular Diversity Preservation International, Basel, Switzerland. This article is an open-access article distributed under the terms and conditions of the Creative Commons Attribution license (http://creativecommons.org/licenses/by/3.0/). 